\title{
ソイルベントナイト遮水壁の自己修復性に関する実験的検討†
}

\author{
高井敦史* 中澤祐 樹** 佐 野和 文*** \\ 乾徹* 勝見 武*
}

\section{Experimental Study on Self-Sealing Capability of Soil-Bentonite Cutoff Walls}

by

Atsushi TAKaI ${ }^{*}$, Yuki NaKaZawa ${ }^{* *}$, Kazufumi Sano ${ }^{* * *}$, Toru InUI ${ }^{*}$ and Takeshi Katsumi ${ }^{*}$

Vertical cutoff walls using low-permeable materials are often constructed at contaminated sites to contain the contaminants and to prevent their migration in the aquifer. Although soil-bentonite cutoff walls can be expected not to lead shear failure even against ground motion due to its softness, cutoff walls are possible to be hydraulically damaged with slip failure or crack. In this study, laboratory-scale hydraulic conductivity tests were conducted with a flexible-wall permeameter, with emphasis on the self-sealing capability of soil-bentonite with hydraulic defects. In order to simulate cutoff walls with defects, specimens with a crack or hole were subjected to permeation. We found as a result that hydraulic conductivity values decreased with time due to the self-sealing capability of soil-bentonite regardless of $\mathrm{CaCl}_{2}$ concentration of base soil. After 4-day permeation, the average hydraulic conductivity of specimens with hydraulic defects was up to 2.2 times that without the defects, while leakage along the cracks were relatively higher with higher initial $\mathrm{CaCl}_{2}$ concentration of base soil. It can be assumed that the self-recovery of soil-bentonite in hydraulic conductivity can be attributed to both the re-swelling of bentonite to non-cations permeant and to shrinkage of crack face and hole due to the softness of soil-bentonite. Thus, even when hydraulic defects occur in cutoff walls, soil-bentonite can recover its hydraulic barrier performance within several times of original hydraulic conductivity with time.

\section{Key words:}

Containment, Hydraulic barrier performance, Self-recovery, Bentonite, Chemical compatibility, Hydraulic defects, Swelling

\section{1 緒言}

土壌污染対策法の改正施行や企業の社会的責任の向上 等の社会的背景を受け, 土㙵污染への対策は益々重要と なっている．対策措置には污染土壌の掘削除去が広く採 用されてきたが，既存構造物下に污染が存在する場合や 污染範囲が広範に及ぶ場合には，污染箇所を低透水性の 遮水工で囲み地下水による拡散を防ぐ，原位置封じ込め 工法が有効である. 本研究で対象とするソイルベントナ イト（以下 SB）は，原位置土に粉体のベントナイトを直 接混合・撹挥することによって構築される低透水性材料 であり ${ }^{1), 2)}$, 施工後も高い柔軟性があり変形追随性を発揮 しうる特徵を有していることから, 地震時にも地盤変状 を許容し遮水性能を維持することが期待できるが，す心゙ り破壊や残留変形による損傷の発生も想定される. 污染 物質の外部への漏出を防止するためにも, SB の自己修復 性は他の材料と比べ極めて有利である ${ }^{3)}$ が, 自己修復性と 母材間隙水中の電解質との関係を評価した例はない，SB の遮水性能は, 溶液に接すると吸水して膨らむべントナ イトの膨潤性に依存しており, 電解質を含む溶液に最初 に曝された場合には膨潤が阻害され, SB の遮水性能が低 下寸ることが明らかになっていることからも3),4), これら の事象を定量的に把握しておくことは極めて重要である.
そこで本研究では, 母材間隙水の初期電解質濃度を変 化させた SB を作製し, 人為的にクラック等の水理的損傷 を設けた供試体に対して透水試験を行い, 自己修復性に 及ぼす電解質濃度の影響を評価した。

\section{2 実験方法}

地下水流による污染物質の輸送は砂地盤において特に 顕著となることから, 鉛直遮水壁は一般的に砂地盤に打 設される. そのため, 砂地盤を模擬し珪砂 7 号 (土粒子密 度は $2.68 \mathrm{Mg} / \mathrm{m}^{3}$, 粒度は砂分が $96.5 \%$, 細粒分が $3.5 \%$ ) を SB の母材に用いた. TRD 工法による SB 遮水壁の実施 工においては, Fig. 1 に示すとおり初めにベントナイト懸 濁液を吐出・擋拌しながら先行掘削し, 施工性を確保する ため地盤の流動性を高めた後, 粉体状のベントナイトを 添加・擋拌して構築される ${ }^{5)}$. その手順を再現するため, 飽和砂地盤を想定した含水比 $26.0 \%$ の硅砂に, フロー值 （JIS R 5201 に準拠）が $150 \mathrm{~mm}$ となるよう 10\%濃度のべ ントナイトスラリーを母材に対して $15 \mathrm{~kg} / \mathrm{m}^{3}$ となるよう 添加, ソイルミキサーで約 2 分間撹拌した後, 乾燥状態の 粉体ベントナイトを母材に対して $100 \mathrm{~kg} / \mathrm{m}^{3}$ 添加し，再 度混合・攪拌しSBを作製した。

本研究ではすべてのケースで $\mathrm{Na}$ 型ベントナイト（土粒 子密度は $2.79 \mathrm{Mg} / \mathrm{m}^{3}$, モンモリロナイト含有率は $48.0 \%$,

$\dagger \quad$ 原稿受理 平成 27 年 6 月 10 日 Received June 10,2015 C2016 The Society of Materials Science, Japan

* 正会員 京都大学大学院地球環境学堂 † 606-8501 京都市左京区吉田本町, Graduate School of Global Environmental Studies, Kyoto Univ., Sakyo-ku, Kyoto 606-8501

** 京都大学大学院地球環境学舎修士課程 †606-8501 京都市左京区吉田本町, Graduate School of Global Environmental Studies, Kyoto Univ., Sakyo-ku, Kyoto 606-8501

*** 日揮㑣 テ220-6001 横浜市西区みなとみらい, JGC Corporation, Nishi-ku, Yokohama 220-6001 


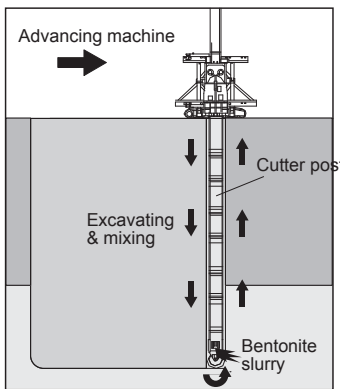

1) Trench cutting with the addition of bentonite slurry

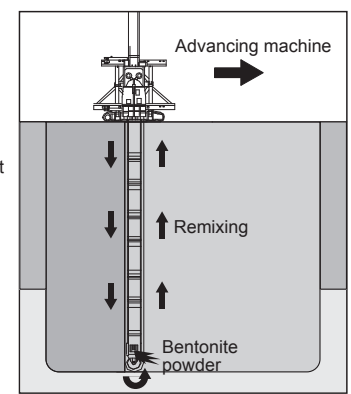

2) Re-mixing the bentonite powde in the trench
Fig. 1 Construction of SB cutoff walls by TRD method.

Table 1 Experimental conditions for hydraulic conductivity test.

\begin{tabular}{lll}
\hline $\begin{array}{l}\text { Initial } \mathrm{CaCl}_{2} \text { concentration } \\
\text { in pore water }(\mathrm{mol} / \mathrm{L})\end{array}$ & $\begin{array}{l}\text { Condition of } \\
\text { specimen }\end{array}$ & $\begin{array}{l}\text { Wet density* } \\
\left(\mathrm{g} / \mathrm{cm}^{3}\right)\end{array}$ \\
\hline \multirow{3}{*}{0} & Undamaged & 1.84 \\
& With crack & 1.81 \\
& With hole & 1.83 \\
\hline \multirow{2}{*}{0.02} & Undamaged & 1.84 \\
& With crack & 1.83 \\
& With hole & 1.82 \\
0.05 & Undamaged & 1.87 \\
& With crack & 1.84 \\
& With hole & 1.84 \\
\hline
\end{tabular}

*After preconsolidation and before permeation

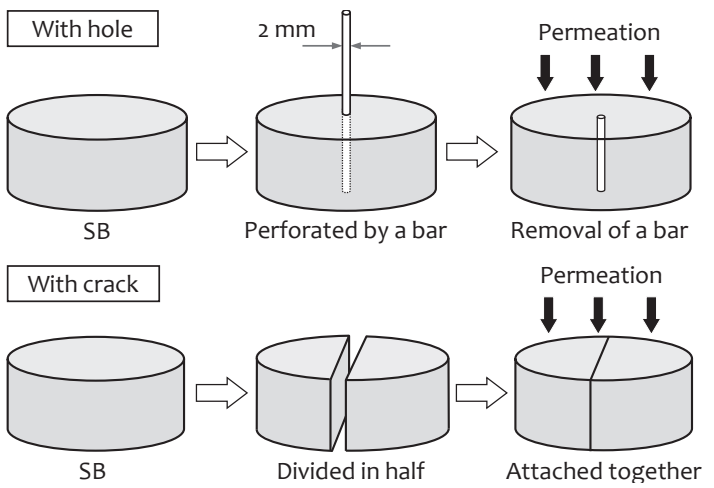

Fig. 2 Preparation of SB specimens with crack or hole.

液性限界および塑性限界はそれぞれ 473.9\%，26.6\%）を用 いた.母材の間隙水に電解質が含まれるケースでは, $\mathrm{CaCl}_{2}$ 溶液を用いて所定の濃度となるよう硅砂の含水比を調整 した後，ベントナイトを添加した．実験条件は Table 1 に 示すとおりであり, $\mathrm{CaCl}_{2}$ 濃度は $0,0.02,0.05 \mathrm{~mol} / \mathrm{L}$ の 3 通りとなるよう調整した。

透水試験には，ASTM D5084 に準拠した柔壁型透水試 験装置を用いた. 初めに $\mathrm{SB}$ 遮水壁の現場データに基づき $1.80 \mathrm{~g} / \mathrm{cm}^{3}$ の湿潤密度で直径 $6.0 \mathrm{~cm}$, 高さ $2.0 \mathrm{~cm}$ の圧密セ ルに SB を充填し，セルごと 48 時間水中脱気を行い飽和 度を高めた。 その後, $19.6 \mathrm{kPa}$ で 24 時間, $39.2 \mathrm{kPa}$ でさら に 24 時間予備圧密を行った後, 压密セルから供試体を押 し出し透水試験装置にセットした．本研究では損傷を受 けた SB 遮水壁の自己修復性を評価するため，き裂あるい は貫通孔を設けた供試体についても実験を行った。各供
試体の作製手順は Fig. 2 に示すとおりであり，き裂を有す る供試体は, 圧密セルから取り出した供試体を直径方向 にワイヤーソーで 2 分割した後, 切断面を再度密着させ 試験に供した. 貫通孔を有する供試体は, 透水方向に直径 $2 \mathrm{~mm}$ のステンレス棒を貫通させた後，棒を取り除き試験 に供した. 各供試体を試験装置に設置した後, 供試体側面 に側壁漏れを防ぐためシリコングリスを塗布し，ゴムメ ンブレンで覆い供試体上部および下部に O-リングを取り 付けた. 装置を組み立てアクリル容器内に水を満たし, 30 $\mathrm{kPa}$ の拘束圧を与え，30５0 の動水勾配で透水を開始し た. 透水溶液には, 電解質を含まない溶液として水道水を 使用し，既往の研究 6)より 70〜80 時間でベントナイトの 膨潤が終了とすることから，透水開始から約 90 時間で試 験を終了した. 以下では, き裂および貫通孔を有する供試 体を用いた透水試験を，それぞれ界面透水試験および開 孔透水試験と称する. 本研究では, 一般的な SB 遮水壁の 壁厚が $55 \mathrm{~cm}$ であることを考慮し, 最終処分場の不透水 性地層に係る基準に基づき，トラベルタイムが同等とな るよう, $1.0 \times 10^{-9} \mathrm{~m} / \mathrm{s}$ を $\mathrm{SB}$ の性能基準として評価した.

\section{3 実験結果と考察}

\section{$3 \cdot 1$ 損傷のないSBの耐化学性}

損傷のない SB に対する透水試験結果を Fig. 3 に示す. この結果から, $\mathrm{CaCl}_{2}$ 濃度の上昇に伴い透水係数が高くな り，母材間隙水中の $\mathrm{CaCl}_{2}$ 濃度が $0.05 \mathrm{~mol} / \mathrm{L}$ の場合には, 透水初期において性能基準の $1.0 \times 10^{-9} \mathrm{~m} / \mathrm{s}$ を満たさなく なることがわかる。この結果は，母材の異なる SB を対象 に実施した既往の研究結果 ${ }^{3)}$ とも合致しており, ベントナ イトが電解質溶液に最初に曝露されたことで膨潤が抑制 され，透水に寄与する有効間隙が相対的に大きくなった ためであると考えられる.このことから，既往の研究と同 様に，損傷のない状態であっても母材の間隙水中に含ま れる電解質濃度は, その後の SB の遮水性能に大きく影響 を与えることがわかる。

\section{$3 \cdot 2$ 損傷を有するSBの遮水性能}

界面透水試験における透水係数の経時変化を健全な SB の結果とともに Fig. 4 に示す.ここではき裂の有無に関わ らず透水断面積を $28.27 \mathrm{~cm}^{2}$ とし，ダルシー則が成立する と仮定して見かけの透水係数として表現している. 図に 示すとおり，母材間隙水の $\mathrm{CaCl}_{2}$ 濃度が $0.02 \mathrm{~mol} / \mathrm{L}$ のケー

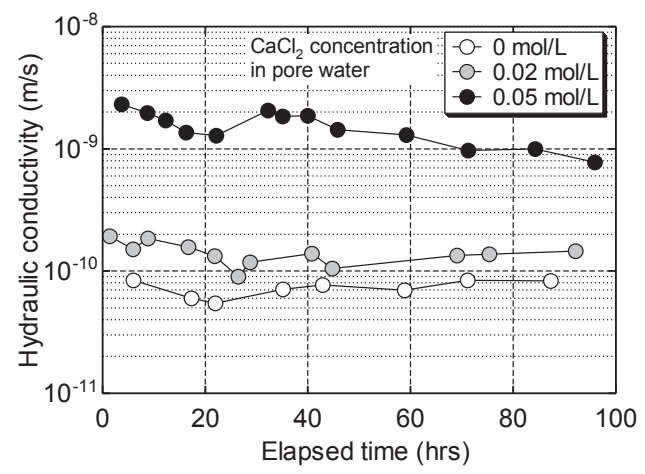

Fig. 3 Temporal change in $k$ of undamaged SBs. 
スでは，き裂の有無が透水初期の透水係数に及ぼす影響 は顕著であり，透水開始直後においては透水係数が 1 才 一ダー程度上昇し，一時的に遮水性能である $1.0 \times 10^{-9} \mathrm{~m} / \mathrm{s}$ を満たさなくなることがわかる. しかしその後, 経時的に 透水係数は減少し，透水開始から 40 時間程度で損傷の無 い供試体の数倍程度の透水係数に回復した。母材間隙水 の $\mathrm{CaCl}_{2}$ 濃度が $0,0.05 \mathrm{~mol} / \mathrm{L}$ の場合には透水直後から透 水係数は同様の值を示しており，健全な供試体と比較し 数倍以内の值を推移した．開孔透水試験での透水係数の 経時変化を Fig. 5 に示す. 図に示すとおり, 透水方向に開 孔が発生した場合であっても，母材間隙水の $\mathrm{CaCl}_{2}$ 濃度に 関わらず，透水初期から透水係数に大きな変化は見られ ず，損傷の無い SB と同等もしくは 3 倍以内の值を示し

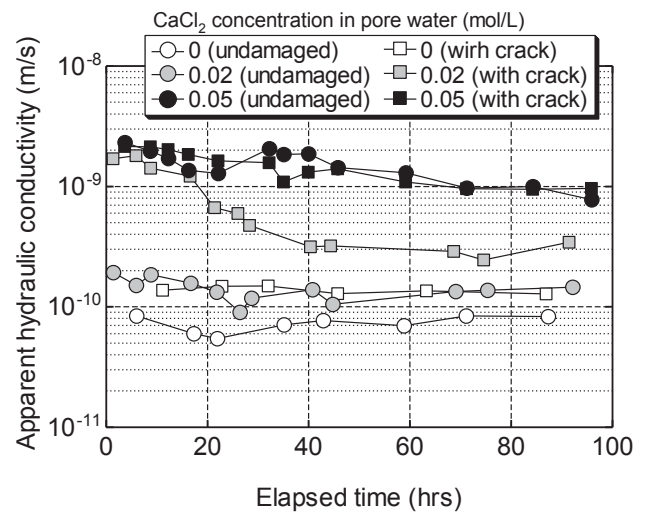

Fig. 4 Temporal change in apparent $k$ with or without crack.

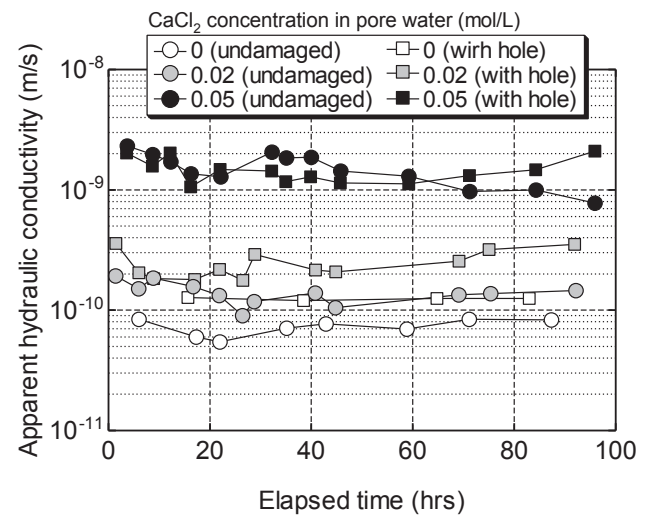

Fig. 5 Temporal change in apparent $k$ with or without hole.

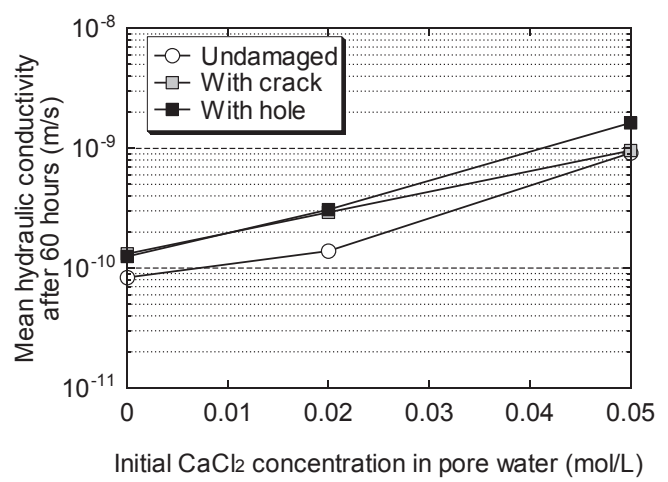

Fig. 6 Comparison of mean $k$ values after the elapse of 60 hours.
た。透水断面積が $28.27 \mathrm{~cm}^{2}$ であり，開孔部が直径 $2 \mathrm{~mm}$ であることを考慮すれば，面積比で $0.1 \%$ 程度の開孔で， ある程度の上載圧が作用する深度であれば, SB の遮水性 能は大きく損なわれない可能性が示唆される.

これらの結果から，損傷を有する場合であっても SB の 見かけの透水係数は健全な供試体の数倍程度の上昇に収 まるといえる. Fig. 6 は透水係数の時間変化が相対的に小 さいと判断できる 60 時閒経過以後の平均值を, 母材閒隙 水の初期 $\mathrm{CaCl}_{2}$ 濃度に対してプロットしたものである.こ の図からも，損傷を受けた場合でも SB は健全な場合の 2 3 倍以内の透水係数を示すと判断でき, 本研究で実施し た条件下であれば，母材に含まれる初期の電解質濃度に 関わらず，自己修復性が期待できるといえる.き裂の有無 により透水係数の差異が最も大きくなったのは開孔透水 試験の $\mathrm{CaCl}_{2}$ 濃度が $0.02 \mathrm{~mol} / \mathrm{L}$ のケースであるが, 健全な $\mathrm{SB}$ の透水係数が $1.4 \times 10^{-10} \mathrm{~m} / \mathrm{s}$, 開孔を有する SB の透水 係数が $3.1 \times 10^{-10} \mathrm{~m} / \mathrm{s}$ であり，約 2.2 倍の上昇に留まって いる.この自己修復性のメカニズムは，1）柔軟性の高い SB が拘束圧の作用により変形することで界面が密着ある いは開孔が閉塞したこと，2) 供試体の間隙水および電解 質を含まない透水溶液に対してベントナイトの再膨潤が 起こり, 損傷部を充填したこと, の 2 つの要因によると考 えられる. 既往の研究では, 関東ロームと砂礫の混合土を 母材として作製した SB を対象に同様の検討を行ってお り，透水開始時に 4 オーダー程度の著しい透水係数の上 昇が確認されたが 3), これは母材の違いにより SB の強度 変形特性が異なるためであると考えられる. 既往の研究 で母材に用いた関東ロームと砂碩の混合土は剛性が高い ために同等の等方圧力であっても開口部が保持されたた めであると考えられることから, SB の強度変形特性は自 己修復性に影響を与えるといえる. 他のケースでは透水 開始直後から透水係数の時間変化が小さいことを考慮す ると, 界面透水試験で $\mathrm{CaCl}_{2}$ 濃度が $0.02 \mathrm{~mol} / \mathrm{L}$ の場合にお いては，拘束圧が作用しても透水方向に連続な水みちが 偶発的に残存していたと考えられるが，このような場合 であっても時間の経過とともにベントナイトの再膨潤に より透水係数を回復したと考えられる.これらのことか ら, SB 遮水壁に水平方向に損傷が発生した場合であって も，上載圧が作用し損傷部分が密着する条件下であれば 地盤中の電解質濃度に関わらず透水係数は経時的に回復 し，初期状態で十分に低い透水係数を有している場合で あれば，損傷を受けても性能基準を超過するまで透水係 数は上昇しないことが明らかとなった。

\section{$3 \cdot 3$ SBの自己修復性に及ぼす電解質の影響}

損傷箇所における漏出量を比較するため, Fig. 6 の各透 水係数と透水断面積 $\left(\approx 28.27 \mathrm{~cm}^{2}\right)$ から, 動水勾配 1 が作 用した場合の単位時間当たりの各流量を算出し, その差 分から損傷部からの流出量を求めた. Fig. 7 に母材間隙水 の初期 $\mathrm{CaCl}_{2}$ 濃度と損傷部からの流出量の関係を示す. 界 面透水試験の $0.05 \mathrm{~mol} / \mathrm{L}$ のケースでは, 損傷の有無で透 水係数に差異が無かったために除外した。この結果から, 


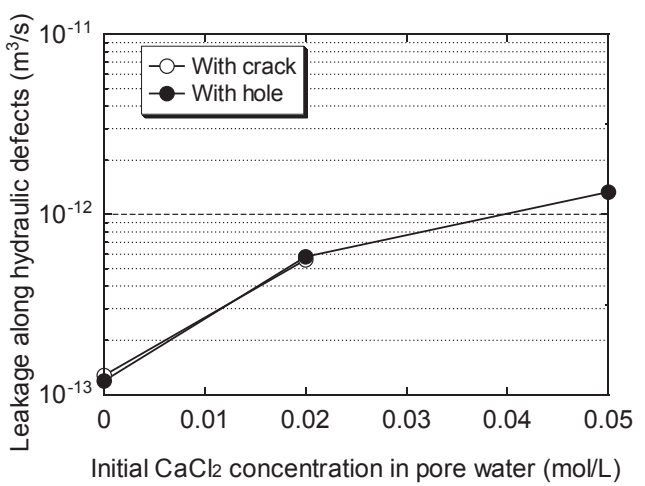

Fig. 7 Initial $\mathrm{CaCl}_{2}$ concentration in pore water versus leakage along hydraulic defects.

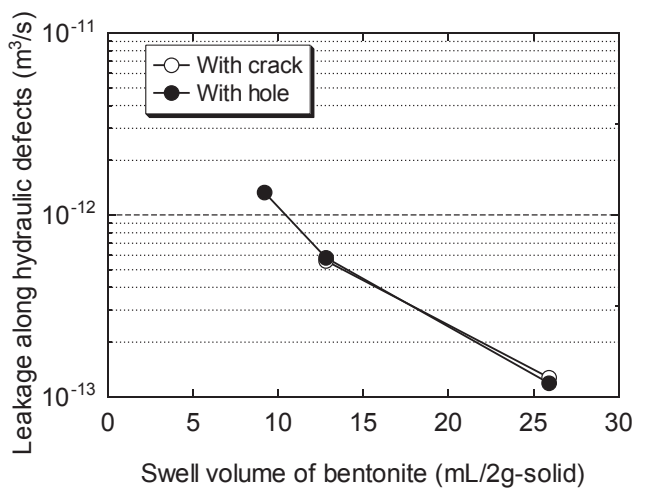

Fig. 8 Swell volume of dry bentonite versus leakage along hydraulic defects.

母材間隙水の初期 $\mathrm{CaCl}_{2}$ 濃度が高くなり $\mathrm{SB}$ そのものの透 水係数が高くなるほど，損傷部における流出量も多くな ることがわかる．このことは，母材間隙水の初期 $\mathrm{CaCl}_{2}$ 濃 度がき裂発生後の SB のベントナイトの再膨潤の程度を 決定することを示唆している。 ベントナイトの再膨潤の 程度が，透水溶液の電解質濃度によって決定されるとす れば，損傷部における流出量は，母材間隙水の $\mathrm{CaCl}_{2}$ 濃度 に関わらずいずれのケースでも同程度まで減少するはず である.よって, 拘束圧による損傷箇所の閉塞が同程度で あると仮定すると，損傷の無い SB の遮水性能と同様に， 母材間隙水の初期の電解質濃度が，損傷発生時の自己修 復性にも影響することが示された。

母材の間隙水と同濃度の溶液に対するベントナイトの 膨潤量（ASTM D 5890 に準じて測定）と，損傷部からの 流出量の関係を Fig. 8 に示す。この結果から, ベントナイ 卜の膨潤量が大きくなるほど線形的に損傷部の流出量が 減少することがわかる。このことから，母材間隙水の初期 $\mathrm{CaCl}_{2}$ 濃度が低いほど $\mathrm{SB}$ 内に層間陽イオンが残存し，透 水溶液に対して再膨潤することで損傷箇所を修復したと 考えられる.よって, 損傷箇所における漏出量と自己修復 の程度は，原地盤に存在する電解質濃度に影響を受ける ものの，電解質濃度が相対的に高い場合であっても健全 な SB の透水係数の数倍以内の值を示していることから, 遮水性能の著しい低下は生じないと判断できる.

\section{4 結 言}

本研究では，母材間隙水の $\mathrm{CaCl}_{2}$ 濃度を変化させて $\mathrm{SB}$ を作製し，供試体に人為的に水理的損傷を設けて透水試 験を行い, 地盤中の電解質濃度が SB の自己修復性に及ぼ す影響を評価した。以下に得られた成果を示す。

(1) ベントナイトが電解質溶液に最初に曝露されると膨 潤が抑制され，SB 中の透水に寄与する有効間隙が相 対的に大きくなる，そのため，損傷のない状態であっ ても母材の間隙水中に含まれる電解質濃度が高くな るほど SB の遮水性能は低くなる。

(2) 本研究で実施した試験条件であれば，母材間隙水の初 期 $\mathrm{CaCl}_{2}$ 濃度に関わらず, 透水開始直後あるいは約 40 時間で損傷の無い SB の数倍以内まで透水係数を自ら 回復しうる.

（3）実現場で SB 遮水壁に水平方向に損傷が発生した場合 であっても，上載圧が作用する条件下であれば SB の 柔軟性およびベントナイトの再膨潤により透水係数 は経時的に回復する. 損傷の発生による透水係数の上 昇は最大で損傷が無い場合の約 2.2 倍であり, 施工時 に十分に低い透水係数を有している場合であれば，損 傷を受けても性能基準を満足しうると考えられる.

(4) ベントナイトの再膨潤に伴う透水係数の回復の程度

は，母材間隙水の初期 $\mathrm{CaCl}_{2}$ 濃度が高くなるほど相対 的に小さく, 流入水に電解質が含まれていない場合で あっても損傷箇所からの流出量は多くなる。

本研究の実施に際し, 嘉門雅史氏 ( (一社) 環境地盤工学 研究所）ならびに荒木進氏 (ライト工業(株) にこご助力い ただくとともに, JSPS 科学研究費補助金（課題番号 24760379）の助成を受けた。ここに記して謝意を表する.

\section{参 考 文 献}

1) J.C. Evans, "Vertical cutoff walls", Geotechnical practice for waste disposal, pp.430-454 (1993) Chapman and Hall.

2) J.P. Britton, G.M. Filz and J.C. Little, "The effect of variability in hydraulic conductivity on contaminant transport through soilbentonite cutoff walls", Journal of Geotechnical and Geoenvironmental Engineering, Vol.131, No.8, pp.951-957 (2005) ASCE.

3) A. Takai, T. Inui, T. Katsumi, M. Kamon and S. Araki, "Factors affecting the hydraulic barrier performance of soil-bentonite mixture cut-off wall", Journal of Japan Society of Civil Engineers, Ser.C (Geosphere Engineering), Vol.68, No.1, pp.1-14 (2012) JSCE.

4) H. Komine, K. Yasuhara and S. Murakami, "Swelling characteristics of bentonites in artificial seawater", Canadian Geotechnical Journal, Vol.46, No.2, pp.177-189 (2009).

5) T. Katsumi, M. Kamon, T. Inui and S. Araki, "Hydraulic barrier performance of SBM cut-off wall constructed by the trench cutting and re-mixing deep wall method", GeoCongress 2008: Geotechnics of Waste Management and Remediation, Geotechnical Special Publication No.177, pp.628-635 (2008).

6) P.V. Sivapullaiah, A. Sridharan and V.K. Stalin, "Swelling behavior of soil-bentonite mixture", Canadian Geotechnical Journal, Vol.33, No.5, pp.808-814 (1996). 